\title{
Rocks with negative cerium anomalies, dredged from Shatsky Rise
}

\author{
Akimasa Masuda ${ }^{1}$ and Shigeru Nagasawa ${ }^{2}$ \\ Department of Earth Sciences, Kobe University, Nada, Kobe $657^{1}$, and \\ Department of Chemistry, Science University of Tokyo, Shinjuku-ku, Tokyo $162^{2}$, Japan
}

(Received October 8, 1975; in revised form November 18, 1975)

\begin{abstract}
Some of basaltic rocks dredged from Shatsky Rise have large negative cerium anomalies. Also these samples have a wide variation in manganese content, and there appears to be some relationship between the extent of cerium anomaly and the manganese content. These observations may be of much significance for discussions of manganese nodule genesis.
\end{abstract}

\section{INTRODUCTION}

In course of studies by our group on rare-earth element (REE) abundances in volcanic rocks from seamounts, a basaltic rock from Shatsky Rise $\left(37^{\circ} 07^{\prime} \mathrm{N}, 162^{\circ} 39^{\prime} \mathrm{E}\right.$, depth $2,920 \mathrm{~m}$ ) exhibited a large negative $\mathrm{Ce}$ anomaly. This finding has compelled us to investigate further the REE in basaltic rocks from this area. These basaltic rocks are highly altered, except for plagioclase component (ARAMAKI, pers. com.). According to his observation under the microscope, lath-shaped plagioclase is developed in the groundmass and mostly appears fresh.

OzIMA et al. (1970) reported $56.7 \mathrm{~m} . \mathrm{y}$. as a minimum age from K-Ar dating. LARSON and CHASE (1972) suggested the age of the ocean floor around Shatsky Rise to be Jurassic to Cretaceous.

The negative Ce anomaly is interesting because of its possible bearing on the positive Ce anomaly in manganese nodules (GoldBERG et al., 1963; GLASBY, 1972-1973; SHIMA, 1974; PIPER, 1974), and of the potential for shedding some new light on the genesis of such nodules.

\section{EXPERIMENTAL}

Nine "basaltic" rocks, one pumice specimen (P19), and one manganese nodule (M7) from Shatsky Rise were investigated. Besides, volcanic rocks from the Erimo and the Second Kashima ("Daini-Kashima") seamount were also examined.

The sample powder (about $500 \mathrm{mg}$ ) was treated with $\mathrm{HF}^{-} \mathrm{HClO}_{4}$ after addition of spike solution, and the REE abundances were determined by mass spectrometric stable isotope dilution as described by MASUdA (1968) and NAKAMURA (1974). The contents of $\mathrm{Mn}, \mathrm{Mg}$ and total $\mathrm{Fe}$ were determined by atomic absorption spectrophotometry, and $\mathrm{K}$ by flame emission spectroscopy. (Total $\mathrm{Fe}$ in seamount rocks was determined colorimetrically.) $\mathrm{H}_{2} \mathrm{O}^{+}$content presented here refers to ignition loss, and thus might involve in part $\mathrm{CO}_{2}$.

As discussed below, attention is paid mainly to REE and Mn. Especially, it should be noted here that the accuracies of REE abundances are usually better than $2 \%$, and $\mathrm{Mn}$ content is reliable within the experimental uncertainties of $\pm 5 \%$. 


\section{RESUlts AND Discussion}

Results of analyses are given in Table 1. The chondrite-normalized REE patterns for the analyzed samples are shown in Figs. 1, 2 and 4; the REE abundances in the Leedey chondrite (MASUDA et al., 1973) are employed to make the Masuda-Coryell plot (MASUDA, 1962; CORYELL et al., 1963).

Of nine basaltic rock specimens from Shatsky Rise, six samples have been found to show large negative cerium anomalies (Fig. 1), while three exhibit no or little anomalies. The ratio of the observed cerium abundance $(\mathrm{Ce})$ to that estimated $\left(\mathrm{Ce}^{*}\right)$ by interpolation between $\mathrm{La}$ and $\mathrm{Nd}$ will serve as a measure for the extent of $\mathrm{Ce}$ anomaly. (An alternative "normal" cerium value, $\mathrm{Ce}^{* *}$, may be estimated by extrapolating from the Sm-Nd join. In general, $\mathrm{Ce} / \mathrm{Ce}^{* *}$ tends to be higher than $\mathrm{Ce} / \mathrm{Ce}^{*}$.) The greatest negative anomaly is observed for $\mathrm{B} 9$ with $\mathrm{Ce} / \mathrm{Ce}^{*}=0.23$. For this rock the chondrite-normalized value of $\mathrm{Ce}$ is lower than those of any heavy REE.

The REE patterns of Shatsky Rise samples with no or little Ce anomalies together with a manganese nodule (M7) with positive anomaly are shown in Fig. 2. Among volcanic rocks, the pattern of B22 is rather unique in having an inflectional point at which the curve breaks in the direction opposite to the usual ones. Also the pumiceous sample (P19) is different in gross REE pattern from all of the basaltic samples with or without Ce anomalies. Admittedly, the analyzed samples are too few to enable us to comment on the characteristics of the normalized REE patterns exclusive of Ce. However, the REE patterns of the samples with negative $\mathrm{Ce}$ anomalies appear more inflectional upwards for the light REE span.

Cerium anomaly Several interpretations of negative anomalies are possible. First,

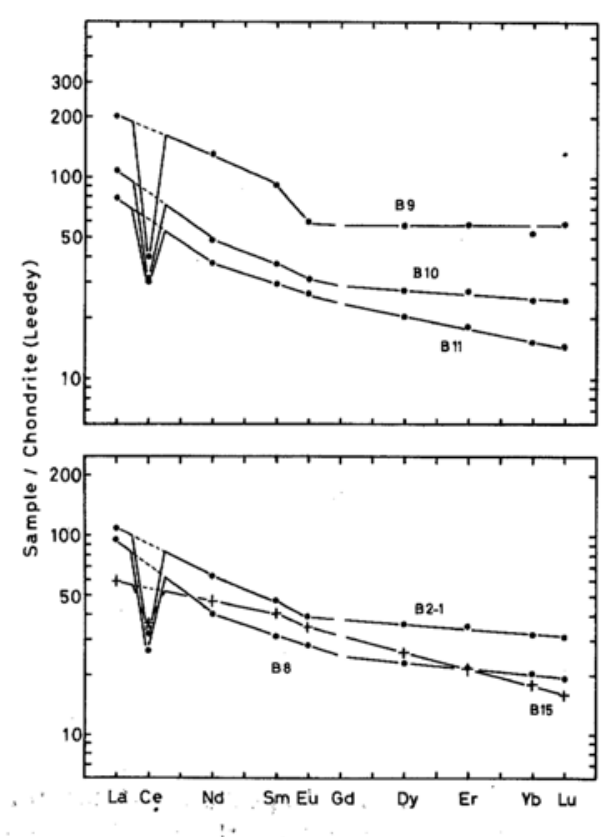

Fig. 1:

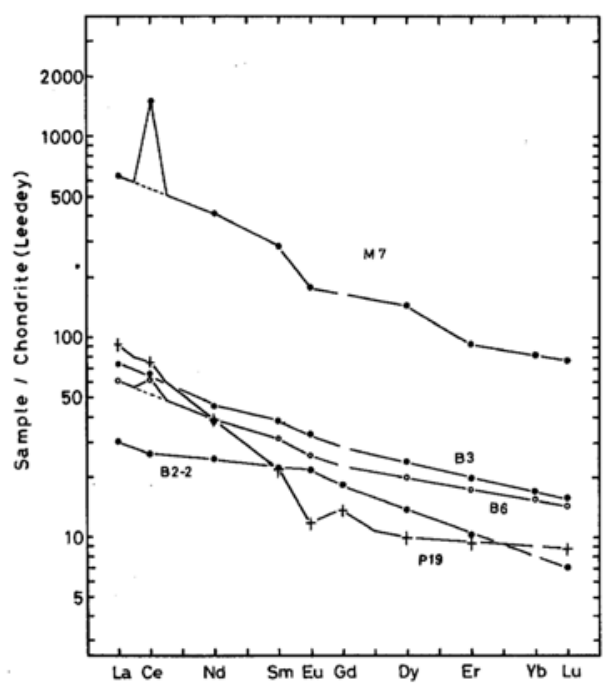

Fig. 2.

Fig. 1. Chondrite-normalized REE patterns of Shatsky Rise samples with negative Ce anomalies.

Fig. 2. Chondrite-normalized REE patterns of Shatsky Rise volcanic rocks with no or little Ce anomalies, together with that of a manganese nodule sample (M7). 


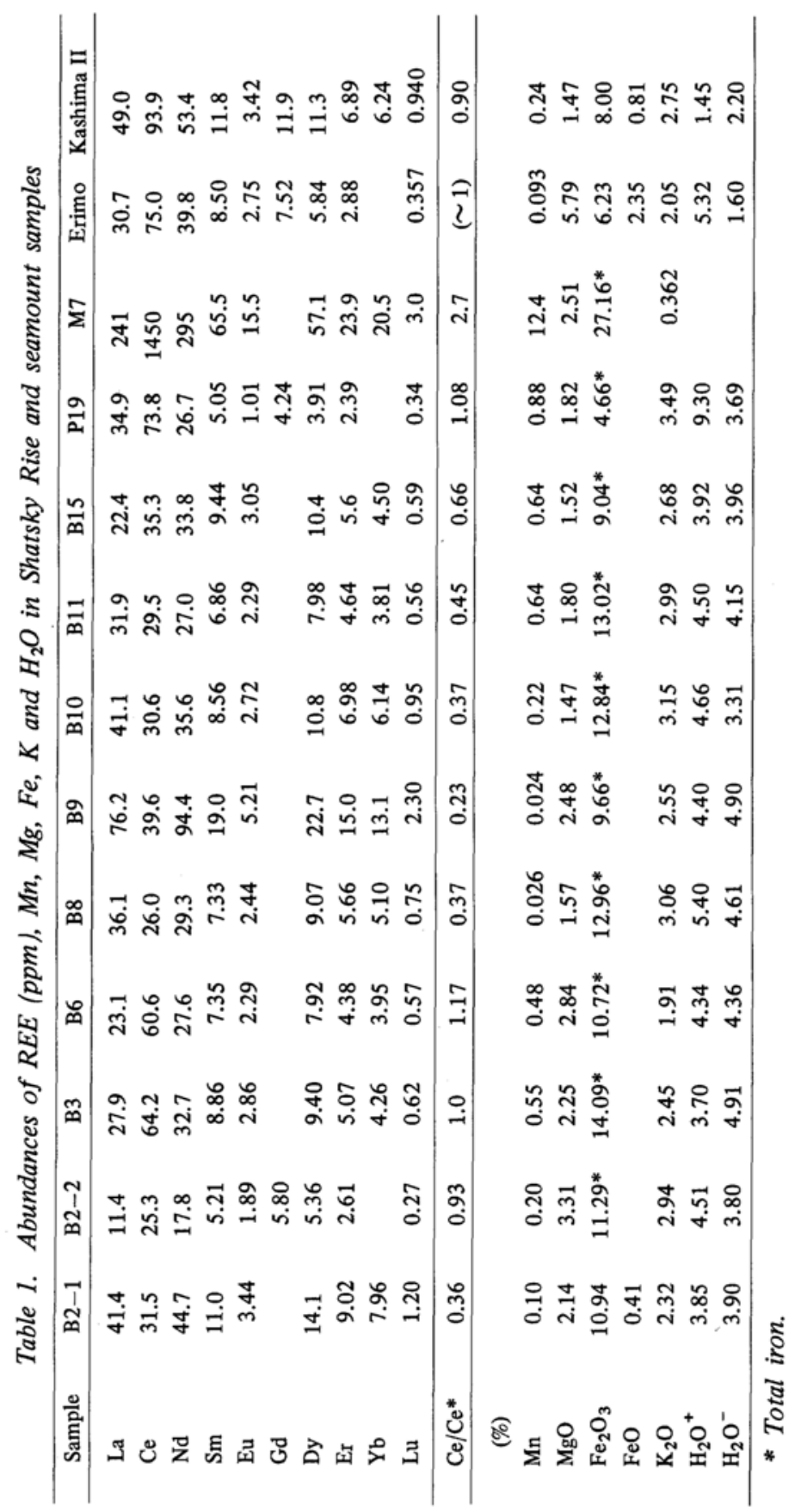


one could speculate on the effect of tetravalent $\mathrm{Ce}$ on the partition coefficient in fractional crystallization; the smaller size of $\mathrm{Ce}^{4+}$ relative to $\mathrm{Ce}^{3+}$ implies that $\mathrm{Ce}$ may be preferentially incorporated into the solid phase. For this effect to operate, the pertinent bulk partition coefficient of Ce must be the same as or higher than those of heavy REE, and perhaps must be near unity. It is supposed that the bulk partition coefficient of $\mathrm{Hf}^{4+}$ with ionic radius $=0.71 \mathrm{~A}$ is large (very roughly, unity) and that the corresponding value for $\mathrm{Th}^{4+}$ with i. $\mathrm{r}$. $=1.00 \mathrm{~A}$ is very small. Possibly, a comparison of $\mathrm{Ce}^{4+}$ ionic radius with those of these cations might provide us with a criterion for semiquantitative judgment. The ionic radius of tetravalent $\mathrm{Ce}$ is taken to be 0.80A (SHANNON and PREWITT, 1969) or 0.92A (Topp, 1965). Because of this ambiguity concerning the ionic size of $\mathrm{Ce}^{4+}$, it is hard for us to advance a discussion from this point of view. However, in order to explain the observed REE patterns with large Ce anomalies such as in B9, it is necessary to assume that the valency state of $\mathrm{Ce}$ had been tetravalent in almost all stages of magmatism since the "initial" formation of magma from the original source which is presumed to have had the relative REE abundances similar to chondrites. Such a model seems unlikely. Also, this interpretation encounters difficulty in explaining the varying extent of $\mathrm{Ce}$ anomalies, particularly, its absence in some cases.

Alternatively, a preferential extraction of Ce by aqueous solution is conceivable as a possible cause of Ce depletion. There can be several variations in this line of interpretation, depending on the nature of the aqueous solution and the assumed physical state of the silicate material. The reactant aqueous solution may be "ordinary" hydrothermal solution, more or less altered brine, natural sea water, or mix tures of these waters. Furthermore, a variety of temperatures are possible. The extraction could have taken place when the silicate material was liquid (buried magma or overflowing lava), or after it solidified. From the occurrence of the rocks under consideration, it would be natural to consider the reacting solution to be more or less brackish water. In addition, the solution is inferred to have been oxidizing enough to assure the conversion of $\mathrm{Ce}^{3+}$ into $\mathrm{Ce}^{4+}$.

Manganese content Since negative Ce anomalies in Shatsky Rise rocks might be related to positive Ce anomalies in manganese nodules (GoldBerg et al., 1963; GLASBY, 1972-1973; SHIMA, 1974; PIPER, 1974), we have determined the Mn content of Shatsky Rise rocks. Fig. 3 shows the relationship between $\mathrm{Mn}$ content and $\mathrm{Ce} / \mathrm{Ce}$. The wide spread in $\mathrm{Mn}$ content is notable. The ratio between the lowest and the highest is 27 , while the corresponding ratios for $\mathrm{MgO}, \mathrm{K}_{2} \mathrm{O}$ and total iron are 2.3, 1.65 and 1.56, respectively. (Cautious examinations assured us that the high dispersion of $\mathrm{Mn}$ content was not due to an accidental mistake in measurement or chemical treatment.)

Samples B9 and B8 with Ce anomalies show the lowest Mn contents, 0.024 and $0.026 \%$, respectively, which is a considerable depletion of $\mathrm{Mn}$, when compared with the average Mn content $(0.15 \%)$ in basalt (DALY, 1933). On the other hand, other samples with $\mathrm{Mn}$ contents much higher than $0.15 \%$ also have negative $\mathrm{Ce}$ anomalies. Overall, there is a rough trend of decreasing $\mathrm{Mn}$ with decreasing Ce but this correlation is not simple.

It might be suspected that high Mn contents $(0.48 \sim 0.64 \%)$ in some basaltic rocks are due to incorporation of manganese nodules. However, the absence of the marked positive $\mathrm{Ce}$ anomaly characteristic of manganese nodules is not consistent with this suspicion.

$\mathrm{H}_{2} \mathrm{O}^{+}$content As seen in Table 1, all of the basaltic rocks from Shatsky Rise show the high $\mathrm{H}_{2} \mathrm{O}^{+}$contents $(3.7 \sim 5.4 \%)$, indicating the high extent of alteration of the samples analyzed. Although it is significant that all of these rocks have high $\mathrm{H}_{2} \mathrm{O}^{+}$contents, emphasis should be placed on the fact that the relative magnitudes of $\mathrm{H}_{2} \mathrm{O}^{+}$contents hardly appear associated with the presence or absence of $\mathrm{Ce}$ anomalies. Also it cannot escape 


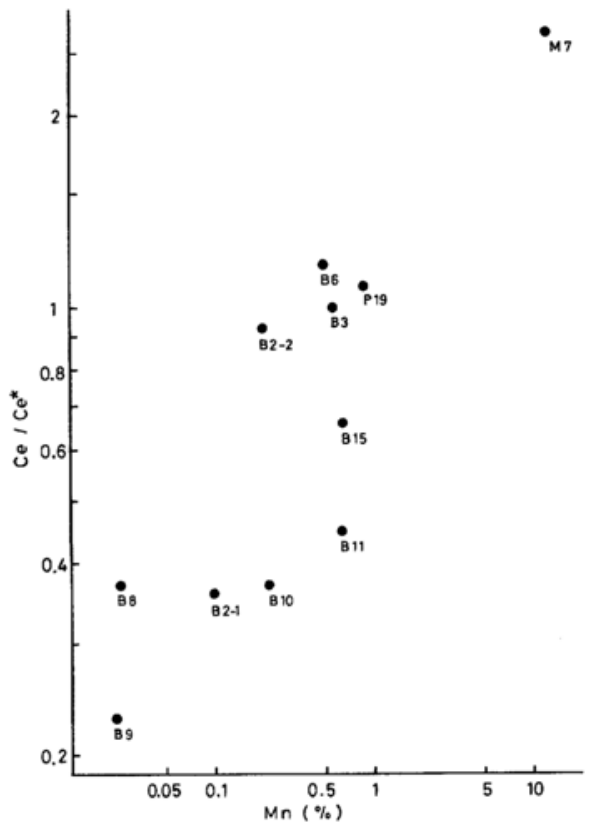

Fig. 3.

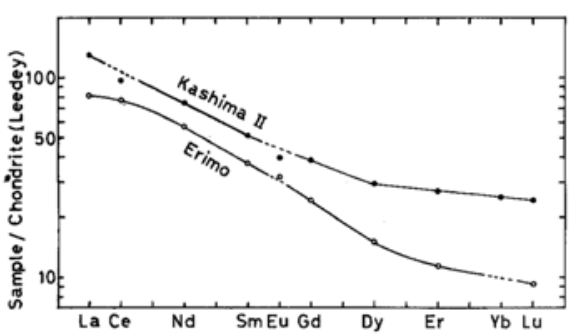

Fig. 4.

Fig. 3. Plot of $\mathrm{Ce} / \mathrm{Ce}$ (cf. text) versus Mn content.

Fig. 4. Chondrite-normalized REE patterns of seamount samples from Erimo and Kashima II.

our notice that $\mathrm{Ce}$ abundance in the pumice (P19) is normal. This suggests that a simple instantaneous reaction between sea water and lava does not give rise to $\mathrm{Ce}$ anomaly.

Meanwhile, an altered submarine basalt with $\mathrm{H}_{2} \mathrm{O}^{+}=6.2 \%$, studied by PHILPOTTS et al. (1969), does not show a tangible Ce anomaly. No cerium anomalies are also observed in two spilitic rocks (HERMANN and WEDEPOHL, 1970) of Devonian to Carboniferous age from NW-Germany, with $\mathrm{H}_{2} \mathrm{O}^{+}$contents of $9 \%$. Two Atlantic Ocean floor palagonites with total water contents of 13 and $10.4 \%$ that were investigated by FREY et al. (1974) show large positive $\mathrm{Ce}$ anomalies. At any rate, to our best knowledge, oceanic volcanic samples with large negative $\mathrm{Ce}$ anomalies are not reported thus far.

General REE pattern Volcanic rocks from two seamounts, Erimo $\left(40^{\circ} 56^{\prime} \mathrm{N}\right.$, $144^{\circ} 54^{\prime} \mathrm{E}$, depth $\left.3,550 \mathrm{~m}\right)$ and Kashima II $\left(36^{\circ} 04^{\prime}, 143^{\circ} 32^{\prime} \mathrm{E}\right.$, depth $\left.3,350 \mathrm{~m}\right)$, were also studied. The overall REE patterns of Shatsky Rise samples with negative $\mathrm{Ce}$ anomalies resemble those of seamount samples under consideration, in particular, that of Kashima II (Fig. 4). Obviously, the REE patterns of rocks from Shatsky Rise and two seamounts reported here are different from those for typical abyssal tholeiites (FREY et al., 1968; KAY et al., 1970; SchILling, 1971; JIBIKI and MASUDA, 1974).

At this point, a short comment is given to the classification of Shatsky Rise rocks. As mentioned above, the microscopic inspection suggests the texture of the originally basaltic rocks (ARAMAKI, pers. com.). However, it is true that the $\mathrm{MgO}$ contents are low for basaltic rocks, but the contents of total iron are high instead; the present state of iron is dominantly ferric. The high $\mathrm{K}_{2} \mathrm{O}$ contents are considered to be due to incorporation from sea water, but it might be prudent to refrain from conclusive words about whether or not the somewhat low $\mathrm{MgO}$ contents are due to extraction by sea water (or aqueous solution having originated therefrom) (BISCHOFF and DICKSON, 1975). It is worth pointing out that the "basaltic" rocks with the exception of B9 appear to have little, if any, Eu anomalies, because this is a common feature for basic rocks. At the same time, note that such a feature is reserved in spite of high alteration demonstrated by the high $\mathrm{H}_{2} \mathrm{O}^{+}$ contents, and that the negative $\mathrm{Eu}$ anomaly for pumice is consistent with its supposedly relatively siliceous composition. 
Additional remarks Provided that differential extraction of $\mathrm{Ce}$ and $\mathrm{Mn}$ from a volcanic source can be verified, it would offer an explanation of the complicated correlation of $\mathrm{Ce}$ anomaly with $\mathrm{Mn}$ content. From such a point of view, the occurrence of MnFe-rich sediments with negative Ce anomalies (BENDER et al., 1971; DyMOND et al., 1973) is not surprising. Some difference in chemical behavior between $\mathrm{Ce}$ and $\mathrm{Mn}$ may be related not only with the Eh values and prevailing oxidation potential, but also with complex ion formation, hydrolysis and polymerization (W ADSWORTH et al., 1957), although our understanding in their details is far from satisfactory at present.

Literature review reveals that there are two major groups of opinions about the origin of marine manganese nodules. One maintains that submarine volcanism is a principal agent supplying manganese to the ocean floor (BONATTI and NAYUdU, 1965; PeTterson, 1959; CoRliss, 1971). Another asserts that manganese is derived through precipitation from sea water, that is, indirectly from the continents (GolDBERG et al., 1963; GoldBERG and ARrhenius, 1958). So far as the chemical aspects are concerned, the latter theory seems to have been favored (PIPER, 1974; KRAUSKOPF, 1957; Crerar and BARNES, 1974). For instance, the mirror-image relationship between the REE pattern of deep-water nodules and that of sea water has been regarded as a cogent fact that favors such an interpretation. We would like to point out that, from the quantitative point of view, this "mirror-image" relationship with respect to $\mathrm{Ce}$ anomaly does not decisively prove the importance of precipitation from the sea water.

Some supporters of manganese derivation from submarine volcanic activity might use the REE data presented here as supporting evidence for a volcanic origin of manganese. But we cannot perfectly rule out the possibility that the $\mathrm{Ce}$ and $\mathrm{Mn}$ depletion in question was caused by low-temperature weathering. At any rate, all the present study implies is that $\mathrm{Ce}$ and $\mathrm{Mn}$ in igneous rocks are mobile and preferentially extractable under certain submarine settings.

\section{ACKNOWLEDGMENTS}

We should like to thank Prof. K. KoBAYASHI, Ocean Research Institute, University of Tokyo, and Prof. M. OzIMA, Geophysical Institute, University of Tokyo, for providing the samples and related data, and Prof. S. ARAMAKI, Earthquake Research Institute, University of Tokyo, for microscopic inspection. Thanks are extended to Mr. T. S HIMOKAWA, Tokyo Metropolitan Isotope Research Center, for technical advice on chemical analyses, to Mr. H. SHIMIZU, Kobe University, for theoretical discussions, and to Mr. N. INENAGA and Mr. T. HoNGO, Science University of Tokyo, for help in chemical analyses.

The research support by Grant in Aid for Fundamental Scientific Research from the Ministry of Education of Japan is gratefully acknowledged.

\section{REFERENCES}

Bender, M., Broecker, W., Gornitz, V., Middel, U., Kay, R., SUN, S. and BiSCAY, P. (1971) Geochemistry of three cores from the East Pacific Rise. Earth Planet. Sci. Lett. 12, 425-433.

BISCHOFF, J. L. and DiCKSON, F. W. (1975) Seawater-basalt interaction at $200^{\circ} \mathrm{C}$ and 500 bars: Implications for origin of sea-floor heavy-metal deposits and regulation of seawater chemistry. ibid. 25, 385-397.

BonatTI, E. and NAYUdU, Y. R. (1965) The origin of manganese nodules on the ocean floor. Am. J. Sci. 263, 17-39.

CORLISS, J. B. (1971) The origin of metal-bearing submarine hydrothermal solutions. J. Geophys. Res. 76, 8128-8138.

Coryell, C. G., Chase, J. W. and Winchester, J. W. (1963) A procedure for geochemical interpretation of terrestrial rare-earth abundance patterns. ibid. 68, 559-566.

Crerar, D. A. and BARNeS, H. L. (1974) Deposition of deep-sea manganese nodules. Geochim. Cosmochim. Acta 38, 279-300. 
DALY, R. A. (1933) Igneous rocks and the depths of the earth. McGraw-Hill, New York.

Dymond, J., CoRliss, J. B., Heath, G. R., Field, C. W., Dasch, E. J. and Veeh, H. H. (1973) Origin of metalliferous sediments from the Pacific Ocean. Geol. Soc. Am. Bull. 84, 3355-3372.

Frey, F. A., HASKIN, L. A., POETZ, J. and HASKIN, M. A. (1968) Rare-earth abundances in some basic rocks. J. Geophys. Res. 73, 6085-6098.

FREY, F. A., BRYAN, W. B. and THOMPSON, G. (1974) Atlantic Ocean floor: Geochemistry and petrology of basalts from legs 2 and 3 of the Deep-Sea Drilling Project. ibid. 79, 5507-5527.

GLASBY, G. P. (1972-1973) Mechanism of enrichment of the rarer elements in marine manganese nodules. Mar. Chem. 1, 105-125.

Goldberg, E. E. and ARrhenius, G. O. S. (1958) Chemistry of Pacific pelagic sediments. Geochim. Cosmochim. Acta 13, 153-212.

GoldberG, E. D., KoIDE, M., SCHMITT, R. A. and SMITH, R. H. (1963) Rare-earth distribution in the marine environment. J. Geophys. Res. 68, 4209-4217.

HerrmanN, A. G. and WEDEPOHL, K. H. (1970) Untersuchungen an spilitischen Gesteinen der variskischen Geosynkline in Nordwestdeutschland. Contr. Mineral. Petrol. 29, 255-274.

JIBIKI, H. and MASUDA, A. (1974) Basalts and serpentinite from the Puerto Rico Trench, 2. Rareearth geochemistry. Mar. Geol. 16, 205-211.

KAY, R., HubBard, N. J. and GaST, P. W. (1970) Chemical characteristics and origin of oceanic ridge volcanic rocks. J. Geophys. Res. 75, 1585-1613.

KRAUSKOPF, K. B., (1957) Separation of manganese from iron in sedimentary processes. Geochim. Cosmochim. Acta 12, 61-84.

Larson, R. L. and Chase, C. G. (1972) Late Mesozoic evolution of the Western Pacific Ocean. Geol. Soc. Am. Bull. 83, 3627-3644.

MASUDA, A. (1962) Regularities in variation of relative abundances of lanthanide elements and an attempt to analyse separation-index patterns of some minerals. J. Earth Sci. Nagoya Univ. 10, 173187.

MasudA, A. (1968) Lanthanides in the Norton County achondrite. Geochem. J. 2, 111-135.

MASUDA, A., NAKAMURA, N. and TANAKA, T. (1973) Fine structures of mutually normalized rareearth patterns of chondrites. Geochim. Cosmochim. Acta 37, 239-248.

NAKAmURA, N. (1974) Determination of $\mathrm{REE}, \mathrm{Ba}, \mathrm{Fe}, \mathrm{Mg}, \mathrm{Na}$ and $\mathrm{K}$ in carbonaceous and ordinary chondrites. ibid. 38, 757-775.

OzIMA, M., KANEOKA, I. and ARAMAKI, S. (1970) K-Ar ages of submarine basalts dredged from seamounts in the Western Pacific area and discussion of oceanic crust. Earth Planet. Sci. Lett. 8, 237-249.

Petterson, H. (1959) Manganese and nickel on the ocean floor. Geochim. Cosmochim. Acta 17, 209-213.

Philpotts, J. A., SChnetzler, C. C. and HART, S. R. (1969) Submarine basalts: Some K, Rb, Sr, $\mathrm{Ba}$, rare-earth, $\mathrm{H}_{2} \mathrm{O}$, and $\mathrm{CO}_{2}$ data bearing on their alteration, modification by plagioclase, and possible source materials. Earth Planet. Sci. Lett. 7, 293-299.

PIPER, D. Z. (1974) Rare earth elements in ferromanganese nodules and other marine phases. Geochim. Cosmochim. Acta 38, 1007-1022.

Schilling, J.-G. (1971) Sea-floor evolution: Rare-earth evidence. Phil. Trans. R. Soc. Lond., Ser. A 268, 663-706.

Shannon, R. D. and PrewitT, C. T. (1969) Effective ionic radii in oxides and fluorides. Acta Crystallogr. 25B, 925-946.

ShimA, M. (1974) Manganese nodules. Chemistry Today No. 42, 32-42. (in Japanese).

TOPP, N. E. (1965) Chemistry of the rare-earth elements. Elsevier Publ. Co.

WAdsworth, E., Duke, F. R. and GoetZ, C. A. (1957) Present status of cerium (IV) - cerium (III) potentials. Anal. Chem. 29, 1824-1825. 